\title{
Effect of nitrogen on activity of peptide hydrolases and protein content in caryopses and flag leaf of barley in ontogenesis
}

\author{
$R S$ Gamzaeva ${ }^{1, *}$ \\ ${ }^{1}$ St. Petersburg State Agrarian University, Peterburgskoe Shosse, 2, 196601, Pushkin, St. Petersburg, \\ Russia
}

\begin{abstract}
The aim of the research was to study the influence peculiarities of different levels of nitrogen nutrition on the activity of peptide hydrolases and protein content in ontogeny of barley plants. The paper discusses the content of total nitrogen, protein and the dynamics of activity of proteolytic enzymes during ontogenesis of barley plants. The activity of peptide hydrolases, the content of protein and total nitrogen were determined in four developmental phases in the flag leaf and forming caryopses of barley. The aim of the work was to determine the effect of different levels of nitrogen on the quantitative content of protein, the total amount of nitrogen, as well as on the activity of acidic and neutral peptide hydrolases. In the course of the research, the following features were revealed: 1. The content of total nitrogen and protein, as well as the activity of proteases, depended on the developmental phase and on the level of nitrogen nutrition; 2. Increasing doses of nitrogen contribute to a greater nitrogen outflow from flag leaves into the forming grain; 3 . High nitrogen norms inhibit the activity of peptide hydrolases. 4. The highest rates of activity of acidic proteases were noted in the phase of full ripeness. 5 . The total activity of peptide hydrolases increased in variants with a twoand three-fold nitrogen dose.
\end{abstract}

\section{Introduction}

Nitrogen is one of the most essential elements for plant growth and development. Of all the elements of mineral nutrition, it has the greatest effect on metabolism. It plays an important role in the life of plants, as it is part of organic substances, forming a variety of nitrogenous organic compounds, the content of which in various plant tissues ranges from 5 to $30 \%$. Of the nitrogenous organic compounds, proteins are of the greatest importance, which constitute the main part of protoplasm and, therefore, are the basis of living matter. Also, nitrogen is part of nucleic acids and a number of other vital substances. As suggested in the work by Roberts, the protein content of barley grain is primarily dependent on nitrogen supply. Interestingly, in the phase of cell expansion, nitrogen influx lags behind the rapid increase in cell size, and therefore the percentage of nitrogenous substances decreases.

\footnotetext{
*Corresponding author: r.gamzaeva@yandex.ru
} 
According to Peltonen-Sainio and Babitskaya [2-3], an increase in the yield of barley and other cereals is accompanied by a decrease in protein in the grain. The authors associate the negative correlation, first of all, with the lack of available nitrogen in the soil.

The growth and development of plants are accompanied by certain changes in metabolism at different stages of life. In a growing cell, the synthesis processes are pronounced, and in aging cells, decay processes prevail over the synthesis processes. The most important influence on metabolism is exerted by the growing conditions of plants.

According to the results of research by Polonskiy and Korzhavina [4-5], when using nitrogen-containing fertilizers, the attracting ability of the wheat ear increases. The study of the processes of nitrogen accumulation and its redistribution during ontogenesis in connection with the formation of reproductive and generative organs is a very urgent direction, in view of the fact that it is important in the formation of productivity. The results of studies by Muurinen, Konvalina, Madhava Rao [6-8] show the need to develop barley varieties with increased yield potential and high efficiency of nitrogen use. All grain crops, including barley, are demanding on nitrogen. Research by Pigorev [16] showed that with a lack of nitrogen, especially during the reproductive period of grain development, the positive effect of other elements, especially potassium, is disrupted.

During plant ontogenesis, not only the intensity of protein biosynthesis changes, but also the activity of a number of enzymes associated with the cleavage of proteins and peptides, i.e. peptide hydrolases. Induction or repression of the synthesis processes of any enzymes in a cell is directly proportional to the cell's need for it at a certain stage of ontogenesis, while these processes are dependent on environmental conditions. As studies by Yanova and Chumikin [9-10] show, the baking properties of grain depend on the protein-proteinase complex.

Proteases catalyze the cleavage of the peptide bond - $\mathrm{CO}$ - $\mathrm{NH}$-, therefore, according to the classification of enzymes, they are called peptide hydrolases. Proteases are usually divided into 2 groups: peptidases and proteinases. The former catalyzes the hydrolytic cleavage of polypeptides and dipeptides, while the latter can directly hydrolyze the protein. It has been proved that the molecular structure of the substrate - its "attack" by the enzyme - has a great influence on the action of the enzyme. The results of studies carried out by Leonova [11] showed that the mass of caryopses affects the activity of proteases. Thus, it was noted that the smaller the grain fraction, the higher the activity of proteolytic enzymes and vice versa. The rate of protein cleavage by a proteolytic enzyme largely depends on the presence of certain chemical groups in the protein, for example, sulfhydryl, amine and oxy groups. If these groups in a protein molecule are somehow eliminated, then the rate of protein hydrolysis by the enzyme changes. For example, if the disulfide groups of a protein are restored, the rate of its cleavage by proteinases increases; if hydroxy groups are blocked by benzoylation or acetylation, as a result, the rate of protein hydrolysis decreases. Change in redox conditions in the cell leads to change in the direction of enzymatic reaction. The system of oxidized and reduced glutathione plays an important role in the regulation of redox conditions in a living cell, and, consequently, the rate and direction of the enzymatic reaction associated with the breakdown and formation of protein. According to Järvan [12], sulfur-containing fertilizers have a positive effect on grain quality. One of the main functions of sulfur is that it is part of the sulfhydryl groups that support the tertiary structure of the protein. Another important function of sulfur is the activation of proteolytic enzymes. It is also known that the reversibility of the action of proteolytic enzymes and their synthesizing ability depend not only on the redox conditions under which the enzyme acts, but also on the molecular structure, concentration and structure of substrates. In the research by Vitol and Karpienko [17] on the proteinase complex of malting barley, it was shown that neutral proteinases hydrolyze proteins with the formation of intermediate products with different molecular weights, which indicates in favor of the narrow 
specificity of this group of enzymes, and acidic proteinases, in turn, form with a large number of low molecular weight products of proteolysis. In this way, intracellular proteolysis regulates various aspects of cellular metabolism.

Peptide hydrolases are capable of lysosomal and non-lysosomal degradation of cell proteins. Lysosomal degradation, which occurs mainly at the level of cell membranes, is carried out by acidic peptide hydrolases. Extra-lysosomal occurs due to special neutral peptide hydrolases localized directly in the protoplasm. The role of acidic proteases or peptide hydrolases is primarily manifested during the degradation of aging cell organelles and macromolecules. The results of experiments on the study of proteases carried out by Gridina et al. [13] showed that the activity of acidic proteases in barley grain in the Biom variety depended on climatic conditions. Research carried out by Bakaeva, Samokhvalova and Gamzaeva [14-16] showed that the growing conditions influence the physiological and biochemical characteristics of grain formation. It is known that acid proteases play a leading role in the mobilization of spare proteins during the germination of seeds of various plants. In non-germinated grain, proteinases have very weak activity. During germination, their activity increases sharply, which is due to the transformation of the zymogen into an active enzyme, as well as the activating effect of glutathione, which is contained in a significant amount in the embryo.

When studying the protein-proteinase activity of triticale grain, Vitol's studies [18] showed that the grain of this crop contains acidic proteinases. The optimum of their activity is $\mathrm{PH} 3.5$, which is 2 times higher than the activity of alkaline proteases, which exhibit optimum action at PH 9.5 and 1.5 times higher than neutral proteases. Also, in the course of this study, it was found that all triticale proteinases are involved in the hydrolysis of only their own proteins, and the greatest activity was observed in neutral proteases. Recently, interest in the study of proteases has increased, since they play an important role in the chemical system of plant defense against pathogens. Plants produce protective peptides that can cause a disruption in the structure of cell membranes and, as a result, disrupt the permeability of the latter. These protective peptides include defensins.

The effect of mineral nutrition, in particular nitrogen, on the activity of proteases remains insufficiently studied.

At the moment, there is no reliable theory about the change and manifestation of protease activity. In the process of studying, there is a correlation of their activity with the course of the formation of reproductive organs and the aging process.

\section{Materials, methods and objects of research}

Studies on the effect of different levels of nitrogen nutrition on the quantitative content of total nitrogen and on the activity of peptide - hydrolases during ontogenesis of spring barley plants were carried out in a small experimental field of St. Petersburg State Agrarian University. For this, vessels were used (capacity $5 \mathrm{~kg}$ ). Mineral fertilizers (according to Knop) were introduced into the vessels based on the vessel: potassium chloride (KCl) - $1 \mathrm{~g}$ and double superphosphate $(\mathrm{Ca}(\mathrm{H} 2 \mathrm{PO} 4) 2 \mathrm{x} \mathrm{H} 2 \mathrm{O})$ - $1.2 \mathrm{~g}$. Nitrogen fertilizers in the form of ammonium nitrate (NH4NO3) were added in the amount of $2.2 \mathrm{~g} /$ vessel (N1PK) (single dose). According to the experimental scheme, from 1 to 4 doses of nitrogen (PKbackground, N1PK; N2PK; N3PK; N4PK) were introduced into the soil. Control - PK background (double superphosphate - 1.2 grams, potassium chloride - 1 gram), N1PK (ammonium nitrate - 2.2 grams + PK background), N2PK (ammonium nitrate - 4.4 grams + PK background), N3PK (ammonium nitrate - 6.6 grams + PK background), N4PK (ammonium nitrate -8.8 grams + PK background). 
The activity of peptide hydrolases was determined by the modified Anson method. The total nitrogen content was determined by the wet ashing method. From the amount of total nitrogen, the protein content was calculated using a factor of 5.7 for cereals.

The work studied the activity of acidic $(\mathrm{pH}-4.5)$ and neutral peptide hydrolases $(\mathrm{pH}$ 7.0) during ontogenesis in the flag leaf and in barley caryopses. Determination of enzyme activity and total nitrogen was carried out in four phases of ontogenesis: 1 - early milk ripeness, 2 - milk ripeness, 3 - waxy ripeness, 4 - full ripeness.

The object of research was the Belogorskiy and Potra varieties of spring barley from the collection of the Vavilov All-Russian Institute of Plant Genetic Resources. In the presented paper, we provide data on the Belogorsky variety. The correlation between the accumulation of total nitrogen and the activity of peptide hydrolases was similar in both varieties.

Characteristics of the Belogorsky variety. The growing season is 75 to 85 days. Medium-ripe, medium-sized. Resistant to lodging, shedding, cold, drought, head smut and powdery mildew. The average protein content is 10 to $13 \%$. The grain has good cereal qualities.

\section{Results}

The results of our research showed that along with an increase in the doses of nitrogen fertilizers, the content of total nitrogen and protein in leaves and in caryopses increased. The highest nitrogen content in the flag leaf in the phase of early milk ripeness was observed in the variant with a double dose of nitrogen (table 1).

Table 1. Effect of increasing doses of nitrogen fertilizers on total nitrogen accumulation and protein content in flag leaf of spring barley, $\mathrm{mg} / \mathrm{dry}$ matter.

\begin{tabular}{|c|c|c|c|c|c|c|c|c|}
\hline \multirow{2}{*}{$\begin{array}{c}\text { Test } \\
\text { options }\end{array}$} & \multicolumn{2}{|c|}{$\begin{array}{l}\text { Early milk } \\
\text { ripeness phase }\end{array}$} & \multicolumn{2}{|c|}{$\begin{array}{c}\text { Milk ripeness } \\
\text { phase }\end{array}$} & \multicolumn{2}{|c|}{$\begin{array}{c}\text { Waxy ripeness } \\
\text { phase }\end{array}$} & \multicolumn{2}{|c|}{$\begin{array}{c}\text { Full ripeness } \\
\text { phase }\end{array}$} \\
\hline & $\begin{array}{c}\text { Total } \\
\text { nitroge } \\
\mathrm{n} \\
\text { content } \\
\end{array}$ & $\begin{array}{l}\text { Protein } \\
\text { content }\end{array}$ & $\begin{array}{c}\text { Total } \\
\text { nitroge } \\
n \\
\text { content } \\
\end{array}$ & $\begin{array}{l}\text { Protein } \\
\text { content }\end{array}$ & $\begin{array}{c}\text { Total } \\
\text { nitroge } \\
\mathrm{n} \\
\text { content } \\
\end{array}$ & $\begin{array}{l}\text { Protein } \\
\text { content }\end{array}$ & $\begin{array}{c}\text { Total } \\
\text { nitroge } \\
n \\
\text { content } \\
\end{array}$ & $\begin{array}{l}\text { Protein } \\
\text { content }\end{array}$ \\
\hline $\begin{array}{c}\text { PK - } \\
\text { backgroun } \\
\text { d }\end{array}$ & 1.4 & 8.0 & 0.5 & 2.8 & 0.3 & 1.7 & 0.7 & 4.0 \\
\hline $\mathrm{N}_{1} \mathrm{PK}$ & 3.4 & 19.4 & 2.8 & 12.9 & 2.4 & 14.0 & 1.8 & 10.2 \\
\hline $\mathrm{N}_{2} \mathrm{PK}$ & 5.1 & 29.1 & 3.5 & 20.0 & 2.9 & 16.5 & 2.4 & 13.5 \\
\hline $\mathrm{N}_{3} \mathrm{PK}$ & 3.8 & 21.6 & 4.0 & 23.0 & 3.1 & 18.0 & 3.1 & 14.0 \\
\hline $\mathrm{N}_{4} \mathrm{PK}$ & 4.8 & 27.1 & 3.8 & 22.0 & 4.0 & 23.0 & 1.4 & 8.0 \\
\hline $\mathrm{LSD}_{0.5}$ & 0.7 & 1.1 & 0.4 & 1.9 & 0.6 & 1.2 & 0.9 & 1.1 \\
\hline
\end{tabular}

Our tests revealed that the total nitrogen content in the flag leaf in the control option significantly decreased during the milk ripeness phase, while in the options with nitrogen this indicator remained at the same level, or tended to increase slightly (table 1).

It was also noted that the total nitrogen content, starting from the wax ripeness phase, decreased in all variants. Throughout the experiment, in all test options, the total nitrogen content decreased unevenly. Thus, against the background of one- and two-fold doses of nitrogen, its maximum decrease was observed, and in the options with three- and four-fold doses of nitrogen, the decrease was not so significant. In the control option, even a slight increase was detected. 
The data obtained indicate that the introduction of nitrogen, in comparison with the control, contributes not only to a greater accumulation of total nitrogen, but also provides a greater outflow of nitrogen-containing substances from flag leaves into the forming grain.

When determining the content of total nitrogen in caryopses, the lowest indicators were noted in the phase of early milk ripeness of grain. In the (PK + background) option, as the grain matured, the amount of total nitrogen increased and reached the highest values in the phase of full ripeness (table 2).

Table 2. Effect of increasing doses of nitrogen fertilizers on total nitrogen accumulation and protein content in spring barley caryopses, $\mathrm{mg} / \mathrm{dry}$ matter.

\begin{tabular}{|c|c|c|c|c|c|c|c|c|}
\hline \multirow{2}{*}{$\begin{array}{c}\text { Test } \\
\text { options }\end{array}$} & \multicolumn{2}{|c|}{$\begin{array}{c}\text { Early milk } \\
\text { ripeness phase }\end{array}$} & \multicolumn{2}{c|}{$\begin{array}{c}\text { Milk ripeness } \\
\text { phase }\end{array}$} & \multicolumn{2}{c|}{$\begin{array}{c}\text { Waxy ripeness } \\
\text { phase }\end{array}$} & \multicolumn{2}{c|}{$\begin{array}{c}\text { Full ripeness } \\
\text { phase }\end{array}$} \\
\cline { 2 - 9 } & $\begin{array}{c}\text { Total } \\
\text { nitrogen } \\
\text { content }\end{array}$ & $\begin{array}{c}\text { Protein } \\
\text { content }\end{array}$ & $\begin{array}{c}\text { Total } \\
\text { nitrogen } \\
\text { content }\end{array}$ & $\begin{array}{c}\text { Protein } \\
\text { content }\end{array}$ & $\begin{array}{c}\text { Total } \\
\text { nitrogen } \\
\text { content }\end{array}$ & $\begin{array}{c}\text { Protein } \\
\text { content }\end{array}$ & $\begin{array}{c}\text { Total } \\
\text { nitrogen } \\
\text { content }\end{array}$ & $\begin{array}{c}\text { Protein } \\
\text { content }\end{array}$ \\
\hline $\begin{array}{c}\text { PK - } \\
\text { background }\end{array}$ & 0.3 & 1.7 & 1.0 & 5.7 & 1.9 & 11.0 & 2.0 & 11.4 \\
\hline $\mathrm{N}_{1} \mathrm{PK}$ & 0.5 & 2.8 & 2.3 & 13.1 & 2.4 & 12.5 & 2.7 & 15.4 \\
\hline $\mathrm{N}_{2} \mathrm{PK}$ & 1.1 & 5.5 & 2.7 & 15.4 & 1.7 & 10.0 & 3.3 & 19.0 \\
\hline $\mathrm{N}_{3} \mathrm{PK}$ & 1.3 & 6.3 & 2.5 & 14.2 & 1.5 & 8.5 & 2.9 & 16.5 \\
\hline $\mathrm{N}_{4} \mathrm{PK}$ & 1.5 & 8.5 & 2.6 & 15.0 & 1.2 & 7.0 & 2.1 & 11.9 \\
\hline $\mathrm{LSD}_{0.5}$ & 0.2 & 0.8 & 0.2 & 0.6 & 0.8 & 0.4 & 0.6 & 1.7 \\
\hline
\end{tabular}

It should be noted that the maximum accumulation of total nitrogen was recorded in the phase of full ripeness, with the exception of the option with a fourfold dose of nitrogen. In this option, unlike the others, even a slight decrease in the total nitrogen content was noted (table 2).

It was revealed that the activity of peptide hydrolases was determined by the phase of plant development and depended on the nitrogen dose.

The experimental data also showed that the activity of neutral peptide hydrolases in the flag leaf in the control option significantly increased towards the full ripeness phase (table $6)$.

Table 3. Effect of increasing doses of nitrogen on peptide hydrolase activity ( $\mathrm{g} / 100 \mathrm{~g}$ crude mass) in flag leaf and spring barley caryopses in early milk ripeness phase.

\begin{tabular}{|c|c|c|c|c|c|c|}
\hline \multirow{2}{*}{$\begin{array}{c}\text { Test } \\
\text { options }\end{array}$} & \multicolumn{3}{|c|}{ Flag leaf } & \multicolumn{3}{c|}{ Caryopses } \\
\cline { 2 - 3 } & \multicolumn{2}{|c|}{ Hydrolysis conditions } & \multirow{2}{*}{ Total activity } & \multicolumn{2}{c|}{ Hydrolysis conditions } & \multirow{2}{*}{ Total activity } \\
\cline { 2 - 3 } & 7.0 & 4.5 & & 7.0 & 4.5 & \\
\hline $\begin{array}{c}\text { PK - } \\
\text { background }\end{array}$ & 0.48 & 6.5 & 6.98 & - & 2.2 & 2.2 \\
\hline $\mathrm{N}_{1} \mathrm{PK}$ & 1.50 & 4.2 & 5.7 & 0.90 & 2.8 & 3.7 \\
\hline $\mathrm{N}_{2} \mathrm{PK}$ & 1.90 & - & 1.90 & 1.61 & - & 1.6 \\
\hline $\mathrm{N}_{3} \mathrm{PK}$ & 2.10 & - & 2.10 & 1.45 & 1.5 & 3.0 \\
\hline $\mathrm{N}_{4} \mathrm{PK}$ & 0.90 & - & 0.90 & 0.48 & 1.9 & 2.4 \\
\hline $\mathrm{LSD}_{0.5}$ & 0.18 & 1.6 & - & 0.34 & 0.5 & - \\
\hline
\end{tabular}


Against the background of increasing doses of nitrogen, the activity of neutral peptide hydrolases increased in comparison with the control (PK - background). Their maximum activity was noted in the phase of waxy ripeness both in the flag leaf and in caryopses in the $\mathrm{N}_{2}$ PK option (table 5). An interesting fact is that, in the options with a fourfold dose of nitrogen, the activity of neutral peptide hydrolases in flag leaves was lower than in other options throughout the entire study period. Taking into account interrelation between the activity of neutral peptide hydrolases in leaves with growth processes and physiological differentiation of tissues, it is important that nitrogen is able to increase $\left(\mathrm{N}_{2} \mathrm{PK}\right.$ option $)$ or suppress $\left(\mathrm{N}_{4} \mathrm{PK}\right.$ option) the activity of this group of enzymes. Such changes in enzyme activity prove the binding between protein metabolism, nitrogen nutrition, growth and development of barley plants. It was shown that the activity of acidic proteases $(\mathrm{pH} 4.5)$ against a phosphorus-potassium background also increased towards the phase of waxy ripeness, but, in contrast to neutral $(\mathrm{pH} \mathrm{7.0)}$, strongly decreased in the phase of full ripeness, so in the flag leaf the activity of enzymes was practically not manifested (table 6).

Table 4. Effect of different nitrogen norms on peptide hydrolase activity ( $\mathrm{g} / 100 \mathrm{~g}$ of crude mass) in flag leaf and spring barley caryopses in milk ripeness phase.

\begin{tabular}{|c|c|c|c|c|c|c|}
\hline \multirow{2}{*}{ Test options } & \multicolumn{3}{|c|}{ Flag leaf } & \multicolumn{3}{c|}{ Caryopses } \\
\cline { 2 - 3 } & \multicolumn{2}{|c|}{ Hydrolysis conditions } & \multirow{2}{*}{ Total activity } & \multicolumn{2}{c|}{ Hydrolysis conditions } & \multirow{2}{*}{ Total activity } \\
\cline { 2 - 3 } & 7.0 & 4.5 & & 7.0 & 4.5 & \\
\hline $\begin{array}{c}\text { PK - } \\
\text { background }\end{array}$ & 2.0 & 7.6 & 9.6 & 1.7 & 1.8 & 3.5 \\
\hline $\mathrm{N}_{1} \mathrm{PK}$ & 2.5 & 5.3 & 7.8 & 2.0 & 2.2 & 4.2 \\
\hline $\mathrm{N}_{2} \mathrm{PK}$ & 2.1 & 4.9 & 7.0 & 2.6 & 2.8 & 5.4 \\
\hline $\mathrm{N}_{3} \mathrm{PK}$ & 2.0 & 4.8 & 6.2 & 2.2 & 2.6 & 4.8 \\
\hline $\mathrm{N}_{4} \mathrm{PK}$ & 1.7 & 2.4 & 4.9 & 2.4 & 2.9 & 5.3 \\
\hline $\mathrm{LSD}_{0.5}$ & 0.3 & 0.7 & - & 0.5 & 0.2 & - \\
\hline
\end{tabular}

The introduction of increasing nitrogen norms (in two-, three- and quadruple doses) did not significantly affect the activity of acidic peptide hydrolases in the early milk ripeness phase of the grain, and their influence was manifested only in the milk ripeness phase, but in subsequent phases, starting with wax ripeness, their activity decreased sharply, with the lowest indicators also noted in the option with 4-fold nitrogen dose.

In the grain, the dynamics of the activity of neutral proteases on the phosphoruspotassium background did not differ significantly from the change in the activity of these enzymes in the leaves. The highest activity was observed in the full ripeness phase (table 6 ). When nitrogen fertilizers were introduced, there was a slight increase in the activity of neutral peptide hydrolases in the milk ripening phase of the grain. The maximum values were noted in the option with a three-fold nitrogen norm. By wax ripeness phase, protease activity ( $\mathrm{pH} 7.0)$ increased in all options, minor variation in options was observed in the full ripeness phase, with the exception of $\mathrm{N}_{1} \mathrm{PK}$ option, where previous indices were found (table 6). 
Table 5. Effect of different nitrogen norms on peptide hydrolase activity ( $\mathrm{g} / 100 \mathrm{~g}$ of crude mass) in flag leaf and spring barley caryopses in waxy ripeness phase.

\begin{tabular}{|c|c|c|c|c|c|c|}
\hline \multirow{2}{*}{ Test options } & \multicolumn{3}{|c|}{ Flag leaf } & \multicolumn{3}{c|}{ Caryopses } \\
\cline { 2 - 6 } & \multicolumn{2}{|c|}{ Hydrolysis conditions } & \multirow{2}{*}{ Total activity } & \multicolumn{2}{c|}{ Hydrolysis conditions } & \multirow{2}{*}{ Total activity } \\
\cline { 2 - 3 } & 7.0 & 4.5 & & 7.0 & 4.5 & \\
\hline $\begin{array}{c}\text { PK - } \\
\text { background }\end{array}$ & 3.2 & 1.8 & 5.0 & 10.5 & 2.4 & 12.9 \\
\hline $\mathrm{N}_{1}$ PK & 11.0 & 3.4 & 14.4 & 11.8 & 3.0 & 13.2 \\
\hline $\mathrm{N}_{2}$ PK & 14.0 & 2.8 & 16.8 & 16.5 & 0.7 & 15.7 \\
\hline $\mathrm{N}_{3}$ PK & 12.0 & 2.4 & 14.4 & 17.1 & 1.4 & 18.5 \\
\hline $\mathrm{N}_{4} \mathrm{PK}$ & 9.0 & 1.5 & 10.5 & 14.5 & 0.3 & 14.8 \\
\hline $\mathrm{LSD}_{0.5}$ & 0.9 & 0.6 & - & 1.2 & 0.6 & - \\
\hline
\end{tabular}

During the research, it was revealed that the activity of acidic peptide hydrolases at a fourfold dose throughout the experiment was the lowest. In the option with a single norm of nitrogen, the maximum indicators of the activity of acidic peptide hydrolases were noted (table 5, 6).

Table 6. Effect of different nitrogen norms on activity of peptide hydrolases ( $\mathrm{g} / 100 \mathrm{~g}$ of crude mass) in flag leaf and spring barley caryopses in full ripeness phase.

\begin{tabular}{|c|c|c|c|c|c|c|}
\hline \multirow{2}{*}{ Test options } & \multicolumn{3}{|c|}{ Flag leaf } & \multicolumn{3}{c|}{ Caryopses } \\
\cline { 2 - 5 } & \multicolumn{2}{|c|}{ Hydrolysis conditions } & \multirow{2}{*}{ Total activity } & Hydrolysis conditions & \multirow{2}{*}{ Total activity } \\
\cline { 2 - 3 } & 7.0 & 4.5 & & 7.0 & 4.5 & \\
\hline $\begin{array}{c}\text { PK - } \\
\text { background }\end{array}$ & 8.0 & - & 8.0 & 11.0 & 9.4 & 20.4 \\
\hline $\mathrm{N}_{1}$ PK & 10.8 & 0.4 & 9.9 & 11.8 & 16.7 & 28.5 \\
\hline $\mathrm{N}_{2}$ PK & 11.5 & 2.4 & 13.9 & 16.0 & 12.0 & 28.5 \\
\hline $\mathrm{N}_{3}$ PK & 12.2 & 2.2 & 14.4 & 18.7 & 4.3 & 23.0 \\
\hline $\mathrm{N}_{4}$ PK & 10.4 & 0.1 & 10.5 & 18.2 & 2.8 & 21.0 \\
\hline $\mathrm{LSD}_{0.5}$ & 0.7 & 0.8 & - & 0.7 & 2.2 & - \\
\hline
\end{tabular}

We found that in the dynamics of acidic peptide hydrolases activity both in leaves and in caryopses in the phase of waxy ripeness, there were two types of enzyme activation, namely, a decrease in acidic peptide hydrolases and an increase in neutral peptide hydrolases. A certain feature in the manifestation of proteolytic enzymes activity in time was also noted in other cereals.

\section{Discussion}

Our studies on the effect of different norms of nitrogen fertilizers on the activity of peptide hydrolases and protein content in ontogeny of barley plants showed that the studied proteases perform different functions in the growth and development of spring barley plants. In particular, it was revealed that neutral peptide hydrolases are involved in protein metabolism, while acidic ones accumulate in organs and tissues during aging. Against the background of mobilization of spare proteins during seed germination of various plants, 
acidic proteases play a leading role. This group of enzymes is able to take part in the processes associated with the differentiation of plant cells, which, in turn, is accompanied by a decrease in the number of cellular organelles or is associated with partial or complete loss of protoplasm.

We found that the outflow of nitrogen-containing substances from the leaves is controlled by many factors. Some of the most significant among them are the intensity of grain formation (the attracting factor) and the ability of leaves to synthesize easily mobile organic matter. Based on the data obtained, it can be summarized that with an increased supply of spring barley plants with nitrogen (N4 PK), nitrogen-containing substances from the leaves flow out more slowly compared to plants grown against a background with a lower nitrogen content.

It is also interesting that the highest indicators of the total activity of proteolytic enzymes in the phase of full ripeness were observed in options with one- and two-fold doses of nitrogen, which can contribute to the formation of full-fledged caryopses, and, consequently, an increase in yield, as compared to the PK-background and option with a fourfold dose of nitrogen.

An important role in the formation of mobile, readily available nitrogen-containing substances, such as amino acids and oligopeptides, which are transported to the attracting centers and on which the quality of the crop depends, is played by the level of action intensity of proteolytic enzymes.

\section{References}

1. Roberts T L Johnston A M 2007 Tillage intensity, Crop rotation, and Fertilizer Technology for Sustainable Wheat Production North American Experience Proc. of the 7th Int. Wheat Conf. 27 november-2 december (Springer) pp 178-189

2. Peltonen-Saini P Jauhiainen L Nissila E 2012 Improving cereal protein yields for high latitude conditions European Journal Agronomy 39 1-8

3. Babitsky A F 2008 Relationship between yield and protein content in wheat grain Fertility 4 31-2

4. Polonsky V I Gerasimov S A 2009 Increased productivity of ear of new lines of barley is determined by extensive indicators Bulletin of KrasSAU 4 58-64

5. Korzhavina N Yu 2016 Protein and starch content in grain of winter wheat against background of application of micronutrient fertilizers ZhUSS Modern problems of agro-industrial complex: collection of scientific papers of the 69th Int. Scientific and Practical Conf. pp 104-6

6. Muurinen S Kecemola J Peltonen-Sainio P 2007 Accumulation and translocation of nitrogen in spring cereal cultivars differing in nitrogen use efficiency Agronomy Journal 99 441-9

7. Konvalina P Moudry J Capouchova I 2009 Baking quality of winter wheat varieties in organic farming Int. Conf. (422 NJF Seminar) "Fostering Healthy Food Systems through Organic Agriculture - Focus on NordicBaltic Region” Spec. Issue 2 Pt 2 (Agron. Res.) p 7

8. Madhava Rao K V Raghavendra A S Reddy K Janardhan 2006 Physiology and molecular biology of stress tolerance in plants (Springer) p 345

9. Yanova M A Bratilova N P Dmitriev V E 2008 Formation of baking properties of wheat grain in Krasnoyarsk region Bulletin of KrasSAU 6 184-7

10. Chumikina L V Arabova L I Topunov A F 2009 Biochemical features of changes in protein and enzyme complexes and gluten of triticale grain during germination 
Izvestiya VUZov Food technology 2-3 9-12

11. Leonova S A 2010 Enzymatic activity of wheat grains of various size Izvestiya VUZov Food technology 2-3 13-14

12. Järvan M Edesi L Adamson A Lukme L Akk A2008 Effect of sulfur fertilization on yierd, quality of properties of winter wheat Agron. Res. 2 459-469

13. Bakaeva N P 2018 Protein-protease complex of grain in agricultural technology of winter wheat using mineral and organic fertilizers Bulletin of the Ulyanovsk State Agricultural Academy: scientific and theoretical journal 4 (44) 71-6

14. Samokhvalova E V 2015 Agrometeorological support of scientific research and study of influence of weather conditions on formation of agricultural crops Research report (interim for 2015) Inv. C17(Kinel) 68

15. Gamzaeva R S 2016 Influence of growth regulators on physiological and biochemical parameters and productivity of spring barley Bulletin of the St. Petersburg State Agrarian University. St. Petersburg: SPbSAU $\mathbf{4 6} 75-80$

16. Pigorev I Ya Tarasov S A 2014 Elements of biologization in cultivation technology of winter wheat Bulletin of OrelSAU 5 102-8

17. Vitol I S Karpilenko G P 2007 Protein-proteinase complex of barley grown on different agro background with use of drugs of regulatory action Prikl. Biokhim. Mikrobiol. 43 391-400

18. Vitol I S 2015 Protein-proteinase complex of triticale grain Storage and processing of agricultural raw materials 8 36-9 